\title{
Examination of Studying Approaches of Students at School of Physical Education and Sports in Terms of Different Variables
}

\author{
Cagatay Dereceli \\ Correspondence: Cagatay Dereceli, Adnan Menderes University, Dept Phys Educ \& Sports, Aydin, Turkey.
}

Received: January 14, 2017

doi:10.11114/jets.v5i4.2298
Online Published: March 23, 2017

URL: https://doi.org/10.11114/jets.v5i4.2298

\begin{abstract}
This study aims to examine studying approaches of the students of physical education and school of physical and sports according to various variables. The data of the study conducted in the general scanning model has been collected from 478 students in 2016-2017 teaching year. Studying Approaches Scale has been used to collect data. Besides complementary statistics, $t$ test, multdimensional variance analysis (MANOVA) and Pearson correlation coefficient has been used while analysing the data. It's seen that studying approaches of these students continue on indecision level. Additionaly, it's seen that they don't show significant differences in terms of gender, grade, department according to the data collected with the scale. There hasn't been found a notable link with studying approaches and success either.
\end{abstract}

Keywords: physical education, learning styles, staying approach, Manova

\section{Introduction}

There is a constant increase in knowledge in many areas as a result of the increase in information and communication technologies. Teaching process has shifted from traditional to constructivist. This situation brings new roles both to the teachers and students. The traditional teaching approach in which students receive knowledge passively has been replaced with a new approach in which students re-construct the knowledge with previous experiences under the guidance of teachers. This has brought new responsibilities to the students in addition to requiring more efforts to take more responsibility in learning process (Kolburan-Geçer, 2012).

For the students adapt to changes in this process requires them to be open to life-long learning and to be able to learn what they need to learn when necessary. For this, cognitive, affective, social and physiological characteristics of students need to be taken into consideration for success teaching applications. Individual differences such as learning styles, motivation, personalities, check focus, epistemological beliefs, self-efficacy perception, and genders of students influence learning process (McCoah and Siegle, 2003; Kızılgüneş, Tekkaya and Sungur, 2009; Olpak and Korucu, 2014; Ozan and Çiftçi, 2013; Paulsen and Feldman, 2005; Rodriguez and Cano, 2007; Topkaya, Yaka and Öğretmen,2011).

One of the factors that influence learning process is undoubtedly learning approaches (Olpak and Koruyucu, 2014). Bat1, Tteik and Gürpınar (2010) emphasize learning styles to explain why some students are more successful than others. It's understood that learning approach and studying approach are used interchangeably in studies (Yıldız, 2015).

Özgür and Tosun (2012) state that learning approaches are worth caring and researching during life-long learning process because it affects success directly. The fact that students cannot use effective ways of studying and learning is pointed as one of the most important obstacles in academic success (Chung and Yip, 2002; Erdamar, 2010; Ersoy, 2003; Şen, 2006; Subaşı, 2000).

It is stated that students behave in two different in learning process; in other words, studying/learning approaches include mostly superficial and deeper dimensions (Altun, 2013; Çuhadar, Gündüz \& Tanyeri, 2015; Olpak \& Korucu, 2014).

It is suggested that in superficial and deep learning processes, both approaches lead to different educational consequences when the role of an individual is concerned (Entwistle, 2000). Superficial approach is an approach in which students accept their fears of failure and receive knowledge passively, focus only on what can be used in exams, ignoring goals adn strategies and memorize without questioning. Deep approach; on the other hand, is an approach in which students try to understand all the dimensions of what is being studied, relate to previous experiences by re-forming knowledge and form causal links (Biggs, 1999; Entwisle, 2000; Sabzevari, Abbaszade and Borhani, 2013).

When the studies in the literature are investigated, there are studies on studying approaches of teacher candidates. 
However, there isn't any direct studies on studying approaches of physical education teacher candidates. Physical education teachers bear great responsibilities in involving students in physical activities and helping them gain physical habits in school they work. The candidate teachers of this branch take theory and applied courses during their bachelor's degree education. The theory course they take can be classier as three main groups as general culture, teaching knowledge and area knowledge. Olpak and Korucu (2014) state that determining which approach students use in studying process can play a role in increasing the effectiveness of teaching environment. So, studying approaches of physical education teachers are aimed to be determined in this research.

\section{Method}

\subsection{Method of the Study}

This study is conducted using relational scanning model to determine studying approaches of students of school of physical education and sports. These models are the ones that correlations of two or more variables are inspected and deeply analysed (Karasar, 2009).

\subsection{Study Group}

The study group consists of 478 students of whom 296 males (61.9\%) and 182 females (38.1\%) that study at 4 different schools of physical education and sports. When the grades are concerned, 131 (27.4\%) freshman, $135(28.2 \%)$ juniors, $134(28 \%)$ sophomores and $78(16.3 \%)$ seniors have been studied. The age average of the group is $25.7 \pm .358$, gpa average is $=2.95 \pm .336$.

\subsection{Data Collecting Means (Tools)}

The tools used are "Personal Information Form" and "Studying Approaches Scale" which are prepared by the researchers.

\subsection{Personal Information Form}

It is prepared to determine socio-demographic and personal qualities of the students who are at the study group with expert opinion and literature review. It consists of variables such as age, gender, grade, department and GPA.

\subsection{Studying Approaches Scale}

This scale is developed to determine studying approaches of students in different dimensions by Biggs, kember and Leung (2001). It is adapted to Turkish by Y1lmaz and Orhan (2011). It consists of 20 articles and there are two sub-versions as "superficial studying approach" and "deep studying approach". There are 5 presented options for the 5 point likert scale and these are: "never valid or barely valid (1)", "sometimes valid (2)", "half valid (3)", often valid (4)" and "always or almost always valid (5)". For reliability, Cronbach Alpha coefficient of "deep approach" is 0.79 and it is 0.73 for "superficial approach".

In reliability analysis done for the scale "superficial studying approach" is calculated as .72, "deep studying approach" as .71 and .70 for "throughout the study". As a result, it is concluded that the scale is reliable.

\subsection{Data Analaysis}

Percentage, frequency, arithmetic average and standard deviation which are complementary statistics have not been used in the study. T test is used for independent groups to identify the differences between gender variable and studying approaches. In multiple comparisons of the study, grade, department and multi-dimensional variance analysis (Manova) is used to identify the differences between studying approaches. Pearson Correlation Test is used to identify whether there is a correlation between GPAs of the group and studying approaches.

\section{Findings}

In this part of the study, the averages that students got from the studying approaches scale are given. Besides, students' genders, grades and departmental studying approaches are determined. Results regarding the relationships between grade point averages are included in this part as well. 
Table 1. Findings on studying approaches

\begin{tabular}{|c|c|c|c|c|}
\hline \multicolumn{2}{|l|}{ Articles } & & \multirow{2}{*}{\begin{tabular}{l|l}
$M$ \\
2.83
\end{tabular}} & \multirow{2}{*}{$\begin{array}{ll}\text { Level } \\
\text { Half valid }\end{array}$} \\
\hline & 1. & Studying from time to time makes me feel content. & & \\
\hline & 2. & $\begin{array}{l}\text { I see I need to study enough to create my own comments and results to } \\
\text { feel content. }\end{array}$ & & Frequently valid \\
\hline & 3. & My main goal is to pass the course studying minimum. & 2.24 & Sometimes valid \\
\hline & 4. & $\begin{array}{l}\text { I study hard only for the topics that are taught in the class or listed in } \\
\text { the syllabus. }\end{array}$ & 3.21 & Half valid \\
\hline & 5. & I feel almost every topic is interesting when I pay close attention. & 2.97 & Half valid \\
\hline & 6. & $\begin{array}{l}\text { I find novel topics interesting most of the time and spend extra time to } \\
\text { research them. }\end{array}$ & 2.84 & Half valid \\
\hline & 7. & I don't find the course interesting therefore I don't study hard. & 2.32 & Sometimes valid \\
\hline & 8. & $\begin{array}{l}\text { Even if I don't understand some things, I revise over and over to learn } \\
\text { memorization. }\end{array}$ & 3.33 & Half valid \\
\hline & 9. & $\begin{array}{l}\text { I find sudying as interesting as watching films and listening to music } \\
\text { sometimes. }\end{array}$ & 2.87 & Half valid \\
\hline & 10. & I test myself on important topics till I learn efficiently. & 3.67 & Frequently valid \\
\hline & 11. & $\begin{array}{l}\text { I can pass many exams by solely memorization rather than studying } \\
\text { for important parts. }\end{array}$ & 2.67 & Half valid \\
\hline & 12. & $\begin{array}{l}\text { As I find studying excessively unnecessary, I limit my studies to the } \\
\text { topics that are pre-determined. }\end{array}$ & 2.73 & Half valid \\
\hline & 13. & I study hard because I find what I study interesting. & 2.88 & Half valid \\
\hline & 14. & $\begin{array}{l}\text { I spend most of my time doing further research on the topics that are } \\
\text { discussed in different classes. }\end{array}$ & 2.46 & Sometimes valid \\
\hline & 15. & $\begin{array}{l}\text { I don't find further studying beneficial. When you only need to } \\
\text { familiarize with the topics, further research causes you get tired and } \\
\text { lose time. }\end{array}$ & 2.47 & Sometimes valid \\
\hline & 16. & $\begin{array}{l}\text { I believe that teachers shouldn't expect their students to spend tine on } \\
\text { the topics that will not be included in the exam. }\end{array}$ & 2.99 & Half valid \\
\hline & 17. & I come to class with questions in mind most of the time. & 2.98 & Half valid \\
\hline & 18. & $\begin{array}{l}\text { I find it important to look in most of the reources recommended in the } \\
\text { class. }\end{array}$ & 3.25 & Half valid \\
\hline & 19. & $\begin{array}{l}\text { I find it unnecessary to study for a topic that is unlikely to be included } \\
\text { in the exam.. }\end{array}$ & 2.65 & Half valid \\
\hline & 20. & $\begin{array}{l}\text { I think learning answers of the questions that are likely to be in the } \\
\text { exam is the best way of studying. }\end{array}$ & 3.20 & Half valid \\
\hline & & General Average & 2.90 & Half valid \\
\hline
\end{tabular}

According to the analysis results in Table 1, in terms of studying approaches point averages, the lowest is $(\mathrm{M}=2.89)$ for "I don't find the course interesting therefore I don't study hard." (7th article), the highest $(\mathrm{M}=3.67)$ is for "I test myself on important topics till I learn efficiently" (10th article). 14 articles in the study have concluded with "half valid" $(M=2.60<M=\leq 3.39), 4$ articles have concluded with "sometimes valid" $(M=1.80<M=\leq 2.59)$. It is determined that the average throughout the scale is at the level of "half valid" $\mathrm{M}=2.60<\mathrm{M}=\leq 3.39$ ".

Findings on Gender Variable

Table 2. $t$ Test results of the comparison of studying approaches according to gender variable

\begin{tabular}{llllllll}
\hline Variables & Gender & N & M & S & t & Sd & p \\
\hline Deep Approach & Male & 296 & 3.01 & .637 & -.212 & 476 & .832 \\
& Female & 182 & 3.02 & .554 & & & .005 \\
\hline Superficial Approach & Male & 296 & 2.84 & .654 & 2.829 & 476 & .058 \\
& Female & 182 & 2.68 & .545 & & & \\
\hline \multirow{2}{*}{ Total } & Male & 296 & 2.93 & .458 & 1.897 & 476 & \\
\hline
\end{tabular}


When Table 3 is examined, between the genders and studying approaches, there hasn't been found any significant difference between deep approach $(\mathrm{t}(478)=-.212 ; \mathrm{p}>.05)$ and general $(\mathrm{t}(478)=1.897 ; \mathrm{p}>.05)$. So it can be said that studing approaches of the students in the study group are similar. At the superficial approach level $(\mathrm{t}(478)=2.829 ; \mathrm{p}<.05)$, there is a significant difference according to gender. It can be stated that this difference is for the good of males when the arithmetic average points are examined. As for this finding, it can be stated that studying approaches of males continue more positively than females at the superficial approach dimension.

Table 3. Manova results of the comparison of studying approaches according to grade variable

\begin{tabular}{|c|c|c|c|c|c|c|}
\hline Variable & Grade & $\mathbf{M}$ & $\mathbf{S}$ & Sd & $\mathbf{F}$ & $\mathbf{p}$ \\
\hline \multirow{5}{*}{ Deep Approach } & 1.Grade & 3.07 & .596 & \multirow{4}{*}{$3-474$} & & \multirow{5}{*}{.698} \\
\hline & 2.Grade & 2.99 & .593 & & & \\
\hline & 3.Grade & 3.00 & .572 & & 4.478 & \\
\hline & 4.Grade & 2.99 & .701 & & & \\
\hline & Total & 3.01 & .606 & \multirow{5}{*}{$3-474$} & & \\
\hline \multirow{5}{*}{ Superficial Approach } & 1.Grade & 2.67 & .538 & & & \\
\hline & 2.Grade & 2.83 & .699 & & & \\
\hline & 3.Grade & 2.90 & .609 & & 44.532 & .004 \\
\hline & 4.Grade & 2.65 & .569 & & & \\
\hline & Total & 2.78 & .619 & \multirow{6}{*}{$3-474$} & & \\
\hline \multirow{5}{*}{ Total } & 1.Grade & 2.88 & .407 & & & \\
\hline & 2.Grade & 2.91 & .433 & & & \\
\hline & 3.Grade & 2.95 & .409 & & 41.844 & .138 \\
\hline & 4.Grade & 2.82 & .463 & & & \\
\hline & Total & 2.90 & .425 & & & \\
\hline
\end{tabular}

When Table 3 is examined, between grades and studying approaches of the students, in Deep Approach $(\mathrm{F}(3-474)=.478$, $\mathrm{p}>.05)$ and in the comparison done throughout the scale $(\mathrm{F}(3-474)=.1 .844, \mathrm{p}>.05)$, there is no significant difference. However, there is significant difference in superficial approach dimension $(F(3-474)=4.532, p<.05)$. So, it can be concluded that grade variable is effective on studying approaches in the superficial approach of the scale while it is not in the deep approach and throughout the scale.

Table 4. Manova results of the comparison of studying approaches according to department variable

\begin{tabular}{|c|c|c|c|c|c|c|}
\hline Variables & Grade & M & $\mathbf{S}$ & Sd & $\mathbf{F}$ & $\mathbf{p}$ \\
\hline \multirow{5}{*}{ Deep Approach } & Coaching Training & 3.05 & .532 & & & \\
\hline & Physical Education and Sports Teaching & 2.99 & .628 & & & \\
\hline & Sports Management & 3.07 & .608 & $3-474$ & 1.080 & .357 \\
\hline & Recreation & 2.93 & .658 & & & \\
\hline & Total & 3.01 & .606 & & & \\
\hline \multirow{4}{*}{ Superficial Approach } & Coaching Training & 2.79 & .605 & & & \\
\hline & Physical Education and Sports Teaching & 2.80 & .624 & & & \\
\hline & Sports Management & 2.75 & .576 & $3-474$ & .167 & 919 \\
\hline & Recreation & 2.78 & .690 & & & \\
\hline \multirow{6}{*}{ Total } & Total & 2.78 & .619 & & & \\
\hline & Coaching Training & 2.92 & .402 & & & \\
\hline & Physical Education and Sports Teaching & 2.90 & .427 & 3914 & 443 & 722 \\
\hline & Sports Management & 2.91 & .382 & $3-4 / 4$ & .443 & .123 \\
\hline & Recreation & 2.86 & .505 & & & \\
\hline & Total & 2.90 & .426 & & & \\
\hline
\end{tabular}

When Table 4 is examined, between students' departments and their studying approaches, there is no significant difference in Deep Approach $(\mathrm{F}(3-474)=1.080, \mathrm{p}>.05)$ and Superficial Approach $(\mathrm{F}(3-474)=.167, \mathrm{p}>.05)$ dimensions and average 
points throughout the scale. This can be interpreted as non-occurence of influence of department variable on studying approaches.

Table 5. Correlation between academic success variable and studying approaches

\begin{tabular}{lclll}
\hline $\begin{array}{l}\text { Akademic success } \\
\text { approaches }\end{array}$ & and studying Grade Average & Deep Approach & $\begin{array}{l}\text { Superficial } \\
\text { Approach }\end{array}$ & Total \\
\hline Pearson Correlation & 1 & -.018 & -.046 & -.046 \\
Sig. (2-tailed) & & .699 & .318 & .316 \\
$\mathrm{~N}$ & 478 & 478 & 478 & 478 \\
\hline
\end{tabular}

When Table 5 is examined, there has not been found any correlation between academic success of the students in the study group and their studying approaches with the article the following articles of the scale: "deep approach dimension" $(\mathrm{r}=-.018, \mathrm{p}>.05)$, "superficial approach dimension" ( $\mathrm{r}=-.046, \mathrm{p}>.05)$, and "throughout the scale" (=-.046, $\mathrm{p}>.05)$. From this result, it can be stated that there is no significant relationship between studying approaches and academic success.

\section{Discussion and Conclusion}

Studying approaches of students of school of physical education and sports have been determined in the study. Moreover, it's also determined whether their approaches vary according to gender, grades and departments. The correlation between academic success of students and their approaches has also been included in the study.

To determine the results of students' efforts on education, their studying approaches need to be determined first (Abraham, Vinod, Asha and Ramnarayan, 2008). When students gain effective studying habits, this increase will influence their success positively too (Doğanay and Demir, 2011).

When the averages the students of school of physical education and sports get from studying approaches scale, it is seen that their point averages are at indecision level. Similar results have been concluded in another study conducted by Dönmezi Yazıcı and Demirez (2016). Besides, Akar (2016) has stated that she used both the superficial approach and deep approach in her study moderately. It is stated that the averages of deep approach is higher than those of the superficial approach even though they are both used moderately. Learning and studying approaches express how students approach to academic duties (Mattick, Dennis and Bligh, 2004).

In the comparison in terms of gender variable, there is no significant difference in the averages gathered with deep approach, while there is in the averages gathered with superficial approach for the good of males. Aksu and Kurtuldu (2015) stated that there are differences between students' studying approaches according to gender. It's been concluded that both female and male students' studying approaches are inclined to deep approach. This result does not agree with the results of this research. Dönmez, Yazıcı and Demirz (2016); Ozan and Çiftçi (2013); Olpak and Korucu (2014) suggest that gender variable is not an effective variable on studying approaches.

There is no significant difference determined in studying approaches of the students with deep approach and superficial approach. It can be said that these results agree with the results of the study by Dönmez, Yazıcı and Demirez (2016), Erdamar-Koç (2010) and Ozan and Çiftçi (2013). Similar results can be found in the study of Olpak and Korucu (2014). It is stated that studying approches of the students do not vary significantly depending on their grades. However, there is significant difference between superficial approach and grade level. It is seen that superficial approaches of students at first and fourth grade are lo while they are high in the students at second and third grade. Similar results have been found in the study by Geçer (2012) even though there hasn't been stated any significant difference. In similar studies by Çuhadar, Gündüz and Tanyeli, (2013); Geçer, (2012); Senemoğlu, (2011), significant differences have been found in superficial approach dimension differently than deep approach dimension.

The results show us that there isn't any significant differences between students' departments and studying approaches in at lower dimensions of the scale and throughout it. So it can be stated that departments have no influence on studying approaches. Olpak and Koruyucu (2014) have found similar results in their study as well. They all agree with each other.

Another finding in the study is about whether there is a correlation between academic success of HIGH students and their studying approaches. In the study sampling, there hasn't been such a correlation. However, Deryakulu (2004) stated that studying approaches have an influence on learning and academic performance. In another study by Şen (2006), the fact that students don't use these approaches affectively is presented as a big obstacle for their success. Yağc1 (2015) has found a low but positive and significant correlation between studying approaches and academic grades in deep approach; a low, negative and significant correlation in superficial approach. It can be said that the curriculum that include applied courses of these schools has an influence on the results.

Students of school of physical education and sports need to have efficient knowledge of studying approaches in order to be successful throughout their education living. It will be helpful if they are trained on these studying approaches. In the 
studying approaches of the students of school of physical education and sports are examined in terms of gender, grade, department and gpa variables. Studying approaches can be studied in further research regarding different variables and in more detail with qualitative studies.

\section{References}

Abraham, R. R., Vinod, P., Kamath, M. G., Asha, K., \& Ramnarayan, K. (2008). Learning approaches of undergraduate medical students to physiology in a non-PBL-and partially PBL-oriented curriculum. Advances in Physiology Education, 32(1), 35-37. https://doi.org/10.1152/advan.00063.2007

Akar, H. (2016). Examination of the Relationship between Studying Approaches and Procrastination Tendencies of Teacher Candidates of Elementary Schools with Structural Equation Modeling. Sosyal Bilimler Dergisi, 6(11), 111-135.

Aksu, C., \& Kurtuldu, M. K. (2015). Evaluation of Studying Approaches of Music Teacher Candidates According to Different Variables, 2(4), 200-213.

Altun, S. (2013). Examination of studying approaches of students in terms of university type, department and gender. Eğitim ve Ögretim Araştırmaları Dergisi, 2(2), 227-233.

Batı, A. H., Tetik, C., \& Gürpınar, E. (2010). Learning Approaches Scale, Adapting the New Version to Turkish and Validity\&Reliability Study. Turkiye Klinikleri Journal of Medical Sciences, 30(5), 1639-1646. https://doi.org/10.5336/medsci.2009-15368

Biggs, J. (1999). What the Student Does: teaching for enhanced learning. Higher Education Research and Development, 18(1), 57-75. https://doi.org/10.1080/0729436990180105

Çuhadar, C., Gündüz, Ş., \& Tanyeri, T. (2013). Examination of the relationship between studying approaches and academic self-efficacy of CEIT Students. Mersin Üniversitesi Eğitim Fakültesi Dergisi, 9(1), 251-259.

Deryakulu, D. (2004). Epistemological Beliefs, Y. Kuzgun ve D. Deryakulu (Editörler) Individual Differences at Education (ss. 259-287). Ankara: Nobel Yayın Dağıtım.

Doğanay, A., \& Demir, Ö. (2011). Comparison of Cognitive Awareness of Teacher Candidates with Low and High Academic Success while Studying. Kuram ve Uygulamada Eğitim Bilimleri, 11(4), 2021-2043.

Dönmez, C., Yazıcı, K., \& Demirez, G. M. (2016). Examination of Studying Approaches of Social Sciences Teacher Candidates. International Online Journal of Educational Sciences, 8(2), 227-239. https://doi.org/10.15345/iojes.2016.02.019

Ekinci, N. (2015). The Relationships Between Approaches to Learning and Self-efficacy Beliefs of Candidate Teachers. Hacettepe Üniversitesi Ĕ̈itim Fakültesi Dergisi, 30(1), 62-76.

Entwistle, N., \& McCune, V. (2004). The conceptual bases of study strategy inventories. Educational Psychology Review, 16(4), 325-345. https://doi.org/10.1007/s10648-004-0003-0

Erdamar-Koç, G. (2010). Variables Influencing Studying Strategies of Teacher Candidates. Hacettepe Üniversitesi Ĕ̈itim Fakültesi Dergisi, 38(38).

Ersoy, S. (2003). Investigation of Learning Approaches of 6th, 7th, 8th Grade Students Regarding their Success . Yayınlanmamış Yüksek Lisans Tezi, Selçuk Üniversitesi Sosyal Bilimler Enstitüsü, Konya.

Geçer, A. K. (2012). An Examination of Studying Approaches and Information Literacy Self-Efficacy Perceptions of Prospective Teachers. Eurasian Journal of Educational Research, 49, 151-172.

Kizilgunes, B., Tekkaya, C., \& Sungur, S. (2009). Modeling the relations among students' epistemological beliefs, motivation, learning approach, and achievement. The Journal of Educational Research, 102(4), 243-256. https://doi.org/10.3200/JOER.102.4.243-256

Mattick, K., Dennis, I., \& Bligh, J. (2004). Approaches to learning and studying in medical students: validation of a revised inventory and its relation to student characteristics and performance. Medical Education, 38(5), 535-543. https://doi.org/10.1111/j.1365-2929.2004.01836.x

McCoach, D. B., \& Siegle, D. (2003). The school attitude assessment survey-revised: A new instrument to identify academically able students who underachieve. Educational and Psychological Measurement, 63(3), 414-429. https://doi.org/10.1177/0013164403063003005

Olpak, Y. Z., \& Korucu, A. T. (2014). Investigation of the relationship between learning approaches of teacher candidates and focus of supervision. Eğitim Teknolojisi Kuram ve Uygulama, 4(2). 
Ozan, C., \& Çiftçi, M. (2013). Investigation of learning approach preferences and perceptions of students of education departments . Pegem Ĕgitim ve Öğretim Dergisi, 3(1), 55-66.

Özgür, H., \& Tosun, N. (2012). Examination of deep and superficial learning approaches of teacher candidates in terms of different variables . Mehmet Akif Ersoy Üniversitesi Eğitim Fakültesi Dergisi, 1(24), 113-125.

Paulsen, M. B., \& Feldman, K. A. (2005). The conditional and interaction effects of epistemological beliefs on the self-regulated learning of college students. Research in Higher Education, 46(7), 731-768. https://doi.org/10.1007/s11162-004-6224-8

Rodríguez, L., \& Cano, F. (2006). The epistemological beliefs, learning approaches and study orchestrations of university students. Studies in Higher Education, 31(5), 617-636. https://doi.org/10.1080/03075070600923442

Sabzevari, S., Abbaszade, A., \& Borhani F. (2013). The Assessment Methods and Learning Approaches in Nursing Students of Kerman University of Medical Sciences in Iran. Creative Education 4(2), 160-164. https://doi.org/10.4236/ce.2013.42023

Şen, B. (2006). The relationship between teachering attitudes of classroom teacher candidates and learning and studying strategies . Yayınlanmamış Yüksek Lisans Tezi, Marmara Üniversitesi, Eğitim Bilimleri Enstitüsü, İstanbul.

Senemoğlu, N. (2011). Learning Approaches and Studying Skills of Students of Education Deparment, 36(160), 65-80.

Subaşı, G. (2000). Effects of efficient studying habits training on academic success, academic self concept and studying habits . Eğitim ve Bilim, 25(117), 50-56.

Topkaya, N., Yaka, B., \& Öğretmen, T. (2011). Implementation of Learning and Studying Approaches Inventory and Examination of Its Correleation with Related Structures . Ë̌itim ve Bilim, 36(159), 192-204.

Yağc1, M. (2015). Examination of Studying Approaches of Teacher Candidates at CEIT and Effects on Academic Success . Journal of Kirsehir Education Faculty, 16(3), 261-275.

Yıldız, Y. (2015). Examination of studying approaches of music teacher candidates regarding their academic expectations. Akademik Sosyal Araştırmalar Dergisi, 3(10), 400-414.

Yip, M. C., \& Chung, O. L. (2002). Relation of study strategies to the academic performance of Hong Kong University students. Psychological Reports, 90(1), 338-340. https://doi.org/10.2466/pr0.2002.90.1.338

\section{Copyrights}

Copyright for this article is retained by the author(s), with first publication rights granted to the journal.

This is an open-access article distributed under the terms and conditions of the Creative Commons Attribution license which permits unrestricted use, distribution, and reproduction in any medium, provided the original work is properly cited. 